\title{
Pili Annulati with Severe Trichorrhexis Nodosa: A Case Report and Review of the Literature
}

\author{
Adrianna M. Gonzalez Luis J. Borda Antonella Tosti \\ Department of Dermatology and Cutaneous Surgery, University of Miami Miller School of Medicine, Miami, FL, USA
}

\section{Established Facts}

- Pili annulati is generally classified as a hair shaft disorder without fragility.

- Weathering has been known to occur in pili annulati, but only four cases have reported associated trichorrhexis nodosa or trichorrhexis nodosa-like changes.

\section{Novel Insights}

- Pili annulati hairs appear to have an underlying weakness that predispose them to breakage in the form of trichorrhexis nodosa.

- In our patient with pili annulati, trichorrhexis nodosa was so severe that she had never been able to grow her hair.

- Gentle hair styling practices should be recommended for patients with pili annulati.

\section{Keywords}

Pili annulati · Trichorrhexis nodosa $\cdot$ Hair breakage

\section{Abstract}

Pili annulati is generally classified as a hair shaft disorder without fragility. However, increased susceptibility to weathering is common. Severe breakage due to trichorrhexis nodosa is uncommon. We report a case and review the literature on this topic.

(c) 2018 S. Karger AG, Basel

\section{Introduction}

Pili annulati (PA) is a hair disorder characterized by light and dark bands of the hair shaft, giving the hair a shiny and speckled appearance. Alternating air-filled cavities within the hair cortex are responsible for the banding pattern seen in PA, resulting in the characteristic stripes seen [1]. The scalp is the most commonly affected area and there is a variable age of onset, from childhood to adulthood [2]. Although the tensile strength of hair in PA is normal and the disorder is not typically associated with increased fragility, breakage may occur as a result of

\section{KARGER}

(c) 2018 S. Karger AG, Basel

E-Mail karger@karger.com

www.karger.com/sad
Adrianna M. Gonzalez, B.S.

Department of Dermatology and Cutaneous Surgery

University of Miami Miller School of Medicine, 1600 NW 10th Ave

Rosenstiel Science Medical Building, Room 2023A, Miami, FL 33136 (USA)

E-Mail a.gonzalez86@umiami.edu 

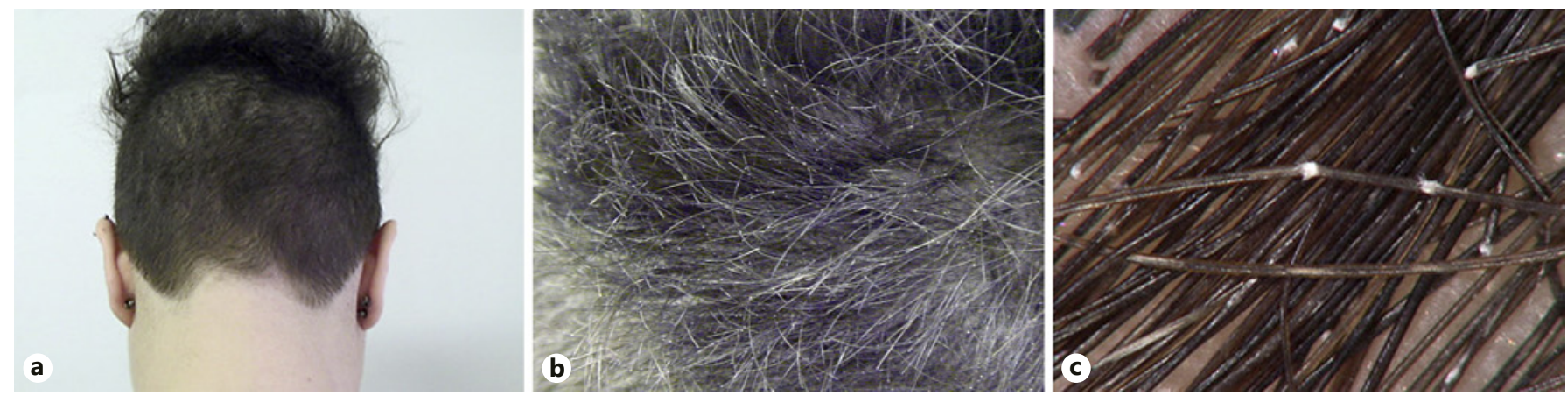

Fig. 1. Clinical Findings. a Hair shaved by patient on bitemporal and occipital area due to intense hair breakage. b Presence of white dots on hairs at the top of the scalp. c Trichoscopy shows multiple white bands consistent with pili annulati and areas of trichorrhexis nodosa within the hair shaft.

Table 1. Cases of pili annulati with trichorrhexis nodosa or trichorrhexis nodosa-like changes in the current literature

\begin{tabular}{|c|c|c|c|c|c|}
\hline Reference & Age, years & Sex & Ethnicity & Clinical diagnosis & Additional findings \\
\hline $\begin{array}{l}\text { Donati } \\
\text { et al. [10] }\end{array}$ & 22 & female & Caucasian & $\begin{array}{l}\text { PA with TN } \\
\text { affecting hairs in } \\
\text { occipital area }\end{array}$ & $\begin{array}{l}\text { breakage occurs } \\
\text { independently of PA } \\
\text { nodes }\end{array}$ \\
\hline Leider [11] & 39 & female & not specified & $\begin{array}{l}\text { PA with TN and } \\
\text { trichostasis } \\
\text { spinulosa }\end{array}$ & $\begin{array}{l}\text { breakage noted to } \\
\text { occur all throughout } \\
\text { hair shaft }\end{array}$ \\
\hline $\begin{array}{l}\text { Feldmann } \\
\text { et al. [8] }\end{array}$ & not specified & not specified & not specified & $\begin{array}{l}\text { PA with TN-like } \\
\text { breaks of hair shaft }\end{array}$ & $\begin{array}{l}\text { breakage noted to } \\
\text { occur at PA nodes }\end{array}$ \\
\hline $\begin{array}{l}\text { Nam } \\
\text { et al. [12] }\end{array}$ & 25 & male & not specified & $\begin{array}{l}\text { PA with TN-like } \\
\text { changes }\end{array}$ & \\
\hline
\end{tabular}

weathering of the altered hair shafts [3]. Trichorrhexis nodosa (TN) is a hair shaft disorder characterized by easy breakage of the hair, due to fracturing of the hair shaft. It is thought to be the result of damage to the cuticular cells and the intercellular binding substances. TN may rarely be associated with some congenital disorders that weaken the hair shaft or it is more commonly acquired following chemical treatments, mechanical trauma, or weathering [4]. We describe the case of PA associated with severe TN in an adolescent with a long-standing history of hair breakage.

\section{Case Report}

A 15-year-old girl presented to the clinic complaining of severe hair breakage since infancy. She stated that as a result of the breakage she constantly had to wear a shaved hairstyle because her hair never grew longer (Fig. 1a). She was otherwise healthy.

Pili Annulati with Severe Trichorrhexis Nodosa
Clinical examination revealed that the hair on the top of the scalp had multiple white dots consistent with TN (Fig. 1b). The tug test was positive. Trichoscopy showed multiple white bands diagnostic for PA and areas of TN within the hair shaft (Fig. 1c). The areas of TN breakage were noted to occur within the PA white bands. Although the patient denied that other family members had a similar problem, trichoscopy examination showed presence of white bands typical for PA in the hair of her 10-year-old brother and her 52-year-old father. Neither of them were aware of the problem and did not complain about hair breakage.

\section{Discussion}

PA is generally classified as a hair shaft disorder without fragility [5]; however, there are a few reports describing increased fragility and breakage in patients with PA [3, 6-8]. These reports describe indentations, cracking, and folding of the hair shaft. Studies utilizing scanning 
electron microscopy to analyze PA hair shafts showed that a few patients had cuticular damage, and in some cases even cortical damage, at the intervals corresponding to the air-filled spaces [8]. TN-like breakage of the hair shaft was noted in some of these damaged nodes, leading to the belief that the nodes in PA could weaken the hair shaft and predispose it to breakage.

An alternate hypothesis to explain the breakage seen in PA stems from the difference in stiffness noted between the light and dark bands when using atomic force microscopy to study the mechanical properties of PA hair shafts [9]. However, in the report of a patient with PA and acquired TN, the use of light microscopy demonstrated that TN occurred in some hairs unaffected by PA and in sites other than the dark PA bands, which favors cuticular damage rather than band stiffness as a predisposing factor to weathering [10]. The increased fragility observed could also partly result from a reduced cysteine content in PA hair, since amino acid analyses have demonstrated that PA hairs have a significantly lower cysteine content and a higher lysine content when compared to normal hairs [7].

In this report we describe a young patient with $\mathrm{PA}$ and severe TN, which is unusual. Although the simultaneous occurrence of PA and TN-like changes may be coincidental, there is evidence to suggest that PA hair likely has an underlying weakness that makes it prone to weathering and breakage, sometimes in the form of TN. To our knowledge, there are 4 reports of patients with PA who have either acquired TN or changes resembling TN (Table 1). One case describes a 39-year-old female with PA, trichostasis spinulosa, and episodic TN that occurred after illness or pregnancy [11]. The other three cases describe adult patients who have overused heating tools or have had harsh hair styling practices $[8,10,12]$. These cases suggest that vigorous mechanical or chemical trauma of a PA hair shaft predisposed to weathering could lead to TN or TN-like changes. Even though fragility is not typically regarded as one of the clinical signs of PA, patients should be advised to use gentle styling practices and to avoid excessive use of heat styling tools.

\section{Statement of Ethics}

The subject has given her consent to publish the details and photographs of this case.

\section{Disclosure Statement}

The authors have no conflicts of interest to disclose.

\section{References}

1 Giehl KA, Dean D, Dawber RP, Leigh I, de Berker DA, Wojnarowska F: Cytokeratin expression in pili annulati hair follicles. Clin Exp Dermatol 2005;30:426-428.

2 Osorio F, Tosti A: Pili annulati - what about racial distribution? Dermatol Online J 2012; 18:10.

3 Werner K, St-Surin-Lord S, Sperling LC: Pili annulati associated with hair fragility: cause or coincidence? Cutis 2013;91:36-38.

4 Cheng AS, Bayliss SJ: The genetics of hair shaft disorders. J Am Acad Dermatol 2008;59: 1-22; quiz 23-26.

5 Singh G, Miteva M: Prognosis and management of congenital hair shaft disorders without fragility - part II. Pediatr Dermatol 2016; $33: 481-487$
6 Akoglu G, Emre S, Metin A, et al: Pili annulati with fragility: electron microscopic findings of a case. Int J Trichology 2012;4:89-92.

7 Giehl KA, Ferguson DJ, Dawber RP, Pittelkow MR, Foehles J, de Berker DA: Update on detection, morphology and fragility in pili annulati in three kindreds. J Eur Acad Dermatol Venereol 2004;18:654-658.

8 Feldmann KA, Dawber RP, Pittelkow MR, Ferguson DJ: Newly described weathering pattern in pili annulati hair shafts: a scanning electron microscopic study. J Am Acad Dermatol 2001;45:625-627.
9 Streck AP, Moncores M, Sarmento DF, Barbosa HS, Weissmuller G, Baetas-Da-Cruz W: Study of nanomechanical properties of human hair shaft in a case of pili annulati by atomic force microscopy. J Eur Acad Dermatol Venereol 2007;21:1109-1110.

10 Donati A, Andriolo AC, Barletta M, Valente $\mathrm{N}$, Romiti R: Pili annulati and trichorrhexis nodosa in the same patient: cause or coincidence? Skin Appendage Disord 2015;1:25-27.

11 Leider M: Multiple simultaneous anomalies of the hair; report of a case exhibiting trichorrhexis nodosa, pili annulati and trichostasis spinulosa. AMA Arch Derm Syphilol 1950; 62:510-514.

12 Nam CH, Park M, Choi MS, Hong SP, Kim MH, Park BC: Pili annulati with multiple fragile hairs. Ann Dermatol 2017;29:254-256. 